fournal of Medical Genetics (1975). 12, 224.

\title{
Variability of acid hydrolase activities in cultured skin fibroblasts and amniotic fluid cells
}

\author{
ELISABETH YOUNG, P. WILLCOX, A. E. WHITFIELD, and A. D. PATRICK \\ From the Department of Chemical Pathology, Institute of Child Health, London, WC1N 1EH
}

Summary. The specific activities of lysosomal hydrolases in cultured skin fibroblasts and amniotic fluid cells showed wide and unpredictable variations between cultures, which may lead to difficulty in differentiating normal, heterozygous, and homozygous cells. However, the variability for a given culture was similar for all enzymes assayed, so that a clearer differentiation of a relative deficiency of a given enzyme could be obtained by expressing its activity in ratio to that of another enzyme. Activity ratios were particularly useful in the evaluation of enzyme levels in cultured amniotic fluid cells. Results of their application to tests of pregnancies at risk for metachromatic leucodystrophy, Krabbe's leucodystrophy, $\mathrm{G}_{\mathrm{M} 1}$-gangliosidosis, and $\mathrm{G}_{\mathrm{M} 2}$-gangliosidosis (Sandhoff variant) are presented.

The increasing use of cultured cells for the diagnosis and prenatal detection of inherited metabolic disorders has led to an awareness of the extent to which the enzymic activity of these cells may be affected by culture conditions. The type of medium (Beutler et al, 1971; Ryan et al, 1972), the $\mathrm{pH}$ of the medium (Ryan et al, 1972), the concentration of fetal calf serum (Kittlick et al, 1973), and other culture materials-such as amphotericin B and trypsin (Uhlendorf, 1970)-have all been shown to influence the levels of enzymic activity of cultured cells. The enzyme content of cells might also be augmented by endocytosis of enzymes present in the serum constituents of culture media (Hors-Cayla et al, 1968). Enzymic activities are also influenced by the state of the cultures at the time they are harvested for assay; these effects are particularly evident with respect to cell density (Leroy et al, 1970; Ryan et al, 1972), time after feeding (Ryan et al, 1972) or subculture (Cristofalo et al, 1967; Okada et al, 1971), age of the culture (Holliday, 1972; Butterworth et al, 1973), and the phase of growth (Pan and Krooth, 1968).

It is essential, therefore, that a laboratory intending to use cultured cells in diagnosis should, whereever possible, attempt to control these effects in order to establish ranges of enzymic activity on which reliable diagnosis can be based. Differences

\footnotetext{
Received 30 August 1974.
}

in the enzyme levels of cultured cells reported from individual laboratories appear to be mainly due to variations in the culture conditions employed; differences may also be due to variations in assay procedures and in the use of protein concentration or other index to which specific activities are referred (Russell, 1969; Kaback and Howell, 1970; Leroy et al, 1970).

Even when all the above variables are controlled by standard practice, it is often found that the range of activity of cultures is very wide, particularly for amniotic fluid cells (Gerbie et al, 1972) and skin fibroblasts (Milunsky et al, 1972). In view of these considerations and because of our interest in the prenatal diagnosis of lysosomal storage disorders, we have studied the variability of acid hydrolase activities of cultured amniotic fluid cells and fibroblasts. Our objective was to determine the ranges of enzymic activity obtained under our particular culture conditions and to investigate means by which the wide ranges of activity found between different cultures might be reduced. These findings have been applied to the interpretation of results of prenatal tests for metachromatic leucodystrophy, Krabbe's leucodystrophy, $\mathrm{G}_{\mathrm{M1}}$-ganglosidosis, and $\mathrm{G}_{\mathrm{M2} 2}$-gangliosidosis (Sandhoff variant). Our experience in the prenatal diagnosis of TaySachs disease has been reported elsewhere (Ellis et al, 1973). 


\section{Materials}

Human albumin-fraction V, 4-nitrocatechol sulphate and p-nitrophenylphosphate were obtained from Sigma (London) Chemical Co Ltd; 4-methylumbelliferyl substrates, bovine brain cerebrosides and p-nitrophenyl palmitate from Koch-Light Laboratories Ltd; Medium 199 and fetal bovine serum from Flow Laboratories; and trypsin from Wellcome Research Laboratories.

\section{Methods}

Cell culture. Skin fibroblasts and amniotic fluid cells were cultured in Medium 199, containing $15 \%$ fetal bovine serum; penicillin $100 \mu \mathrm{g} / \mathrm{ml}$; streptomycin $100 \mu \mathrm{g} / \mathrm{ml}$, and added glutamine $(1 \mathrm{mmol} / \mathrm{l})$ in pyrogenfree distilled water. The medium was sterilized by Millipore filtration.

Cultures were incubated at $37^{\circ} \mathrm{C}$ in an atmosphere of $5 \% \mathrm{CO}_{2}: 95 \%$ air, fed twice weekly, and harvested $24 \mathrm{~h}$ after feeding. Cells were detached with a $0.1 \%$ solution of trypsin in $0.01 \mathrm{~mol} / 1$ sodium citrate, $\mathrm{pH} 7.8$, containing $0.1 \mathrm{~mol} / 1 \mathrm{NaCl}$.

Skin fibroblast cultures. A skin biopsy $\left(1-2 \mathrm{~mm}^{3}\right)$ was cut into several pieces and placed on a glass slide, which was then inverted in a Pyrex Petri dish $50 \mathrm{~mm}$ diameter) and covered with $5 \mathrm{ml}$ of culture medium. Approximately 4 weeks later the pieces of skin were discarded and the fibroblast outgrowths trypsinized from the slide, which was then removed. Culture was continued in the dish until a monolayer was formed; the cells were then subcultured.

Amniotic fluid cell cultures. Amniotic fluid was centrifuged in sterile conical polycarbonate tubes at $400 \mathrm{~g}$ for $10 \mathrm{~min}$ at room temperature. The cell pellet was resuspended gently in $0.3 \mathrm{ml}$ culture medium and added to $50 \mathrm{~mm}$ Pyrex Petri dishes, each dish receiving the cells from approximately $5 \mathrm{ml}$ of amniotic fluid. Culture medium was added and the dishes were left undisturbed for 3 to 4 days, after which they were fed twice weekly. After 2 weeks, the colonies were trypsinized to disperse the cells, which were then allowed to grow to form a monolayer before being subcultured.

Cells harvested by trypsinization were washed with $0.9 \%(\mathrm{w} / \mathrm{v}) \mathrm{NaCl}$ solution and homogenized in ice-cold water using a small hand-operated glass homogeniser of the Potter type. The homogenate was frozen in solid $\mathrm{CO}_{2} /$ methanol and stored at $-15^{\circ} \mathrm{C}$.

Enzyme assays. Whole homogenates of cultured cells were used in all assays. Incubation temperature was $37^{\circ} \mathrm{C}$. All assay mixtures contained $0.1 \%$ human albumin. $\mathrm{N}$-acetyl- $\beta$-D-hexosaminidase was assayed according to the method of Brett et al (1973); $\beta$-galactosidase according to the method of Young et al (1972); galactocerebrosidase according to the method of Bowen and Radin (1969), using the modified substrate solution described by Radin and Arora (1971); and acid esterase according to the method of Young and Patrick (1970), using p-nitrophenyl palmitate as substrate and $10 \mu \mathrm{l}$ of cell homogenate (3-40 $\mu \mathrm{g}$ protein) in a final volume of $150 \mu \mathrm{l}$.

Acid phosphatase activity was measured in a mixture containing $0.1 \mathrm{~mol} / 1$ acetate buffer, $\mathrm{pH} 5.0(50 \mu \mathrm{l}) ; 11$ $\mathrm{mmol} / \mathrm{l} \mathrm{p}$-nitrophenyl phosphate $(50 \mu \mathrm{l})$ and $5 \mu \mathrm{l}$ of homogenate (5-25 $\mu \mathrm{g}$ protein). After $30 \mathrm{~min}$ incubation the reaction was stopped by the addition of $1 \mathrm{~mol} / \mathrm{l}$ Tris-HCl, pH $9.0(300 \mu \mathrm{l})$. After centrifugation, $200 \mu \mathrm{l}$ of the clear supernatant fluid was added to $1 \mathrm{~mol} / \mathrm{l}$ Tris$\mathrm{HCl}, \mathrm{pH} 9.0(200 \mu \mathrm{l})$, and the absorbance measured immediately at $400 \mathrm{~nm}$.

Arylsulphatase A activity was measured in a mixture containing $0.75 \mathrm{~mol} / 1$ acetate buffer $-0.137 \mathrm{~mol} / 1 \mathrm{NaCl}$, $\mathrm{pH} 4.9(100 \mu \mathrm{l}) ; 4.4 \mathrm{mmol} / \mathrm{l}$ sodium pyrophosphate (10 $\mu \mathrm{l}) ; 61 \mathrm{mmol} / 1$ 4-nitrocatechol sulphate $(25 \mu \mathrm{l})$, and $30 \mu \mathrm{l}$ of homogenate (10-50 $\mu \mathrm{g}$ protein). Activity was estimated for the incubation period $20-70 \mathrm{~min}$. At these times the reaction was stopped by the addition of $1 \mathrm{~mol} / 1 \mathrm{NaOH}(400 \mu \mathrm{l})$ and, after centrifugation, the absorbance was measured at $500 \mathrm{~nm}$.

$\alpha$-Galactosidase activity was measured in a mixture containing $0.2 \mathrm{~mol} / 1$ acetate buffer, $\mathrm{pH} 4.4(50 \mu \mathrm{l}) ; 10$ $\mathrm{mmol} / 1$ 4-methylumbelliferyl- $\alpha$-D-galactopyranoside in $0.1 \mathrm{~mol} / \mathrm{l}$ acetate buffer, $\mathrm{pH} 4.4(100 \mu \mathrm{l})$, and $50 \mu \mathrm{l}$ of homogenate (10-30 $\mu \mathrm{g}$ protein). After $30 \mathrm{~min}$ incubation the reaction was stopped by the addition of 0.25 $\mathrm{mol} / 1$ glycine- $\mathrm{NaOH}, \mathrm{pH} 10.4(1.0 \mathrm{ml})$ and the liberated 4-methylumbelliferone measured fluorimetrically.

$\alpha$-Glucosidase activity was measured in a mixture containing $0.1 \mathrm{~mol} / 1$ acetate buffer, $\mathrm{pH} 4.0(100 \mu \mathrm{l})$; $2 \mathrm{mmol} / 1$ 4-methylumbelliferyl- $\alpha$-D-glucopyranoside $(100 \mu \mathrm{l})$ and $25 \mu \mathrm{l}$ of homogenate $(20-30 \mu \mathrm{g}$ protein). After $30 \mathrm{~min}$ incubation the reaction was stopped and fluorescence measured as for $\alpha$-galactosidase above.

The protein content of the supernatant fluid obtained after centrifuging a sample of homogenate at $2000 \mathrm{~g}$ for 5 min was determined by the method of Lowry et al (1951), modified for small volumes. For all homogenates, supernatant protein concentration was directly proportional to total protein.

\section{Results and discussion}

Ranges of acid hydrolase activities of cultured amniotic fluid cells assayed at various stages of subculture from 1 to 5 are shown in Table I. Wide ranges of activity were found for all the enzymes assayed. No correlation between enzymic activity and gestational age was found for any enzyme. Table I also shows that similarly wide ranges were obtained when the activities of a particular subculture (second) were compared. In further experiments, some individual cultures assayed at every stage of subculture from 1 to 5 showed little variation in activities, while in others there was up to a 10-fold variation between subcultures. This variation might be due to the presence of different cell types of differing enzymic constitution at various stages of culture. Comparison of epithelioid and 
TABLE I

ACID HYDROLASE ACTIVITIES OF CULTURED AMNIOTIC FLUID CELLS

\begin{tabular}{|c|c|c|c|c|c|c|c|c|}
\hline \multirow[b]{2}{*}{ Number of cultures } & \multicolumn{2}{|c|}{$\beta$-Galactosidase } & \multicolumn{2}{|c|}{ Galactocerebrosidase } & \multicolumn{2}{|c|}{ Arylsulphatase A } & \multicolumn{2}{|c|}{$\beta$-Hexosaminidase } \\
\hline & 25 & 17 & 24 & 18 & 20 & 15 & 14 & 8 \\
\hline Subculture assayed & $1-5$ & 2 & $1-5$ & 2 & $1-5$ & 2 & $1-5$ & 2 \\
\hline Total number of assays & 73 & 17 & 72 & 18 & 62 & 15 & 52 & 8 \\
\hline $\begin{array}{c}\text { Activity range } \\
\text { Mean } \pm \text { SD }\end{array}$ & $\begin{array}{l}0.55-6.65^{*} \\
2.08 \pm 1.34\end{array}$ & $\begin{array}{l}0.61-6.65^{*} \\
2.66 \pm 1.67\end{array}$ & $\begin{array}{l}0.40-8.59 \dagger \\
2.45 \pm 1.70\end{array}$ & $\begin{array}{l}0.66-8.20 \dagger \\
3.43 \pm 2.10\end{array}$ & $\begin{array}{l}0.12-1.70^{*} \\
0.43 \pm 0.31\end{array}$ & $\begin{array}{l}0.12-1.70^{*} \\
0.52 \pm 0.46\end{array}$ & $\begin{array}{c}3.60-17.60^{*} \\
8.16 \pm 3.44\end{array}$ & $\begin{array}{c}3.60-15.60 \\
8.41 \pm 3.87\end{array}$ \\
\hline
\end{tabular}

* Specific activity expressed as $\mu \mathrm{mol}$ substrate hydrolysed per mg protein per hour.

+ Specific activity expressed as nmol substrate hydrolysed per mg protein per hour.

TABLE II

ACID HYDROLASE ACTIVITIES OF REPLICATE CULTURES OF AMNIOTIC FLUID CELLS

\begin{tabular}{|c|c|c|c|c|c|c|c|c|c|c|}
\hline Culture & $\begin{array}{l}\text { Sub- } \\
\text { culture }\end{array}$ & $\begin{array}{c}\beta \text {-Galacto- } \\
\text { sidase }^{*}\end{array}$ & $\begin{array}{l}\text { Galacto- } \\
\text { cerebro- } \\
\text { sidaset }\end{array}$ & $\underset{\text { sulphatase-A }}{\text { Aryl- }}$ & $\begin{array}{c}\beta-H e x o s- \\
\text { aminidase* }\end{array}$ & $\underset{\mathbf{A}(\%)}{\underset{\text { Hexos- }}{\text { aminidase }}}$ & $\begin{array}{c}\text { Acid } \\
\text { Phosphatase* }\end{array}$ & $\begin{array}{c}\text { Acid } \\
\text { Maltaset }\end{array}$ & $\begin{array}{c}\text { Acid } \\
\text { Esterase* }\end{array}$ & $\begin{array}{c}\alpha-G a l a c t o- \\
\text { sidase }^{*}\end{array}$ \\
\hline $\begin{array}{l}A 56 \\
\text { a } \\
\text { b } \\
\text { c } \\
\text { d }\end{array}$ & $\begin{array}{l}1 \\
1 \\
1 \\
1\end{array}$ & $\begin{array}{l}2.66 \\
3.10 \\
2.61 \\
2.29\end{array}$ & $\begin{array}{l}2.43 \\
2.63 \\
2.33 \\
2.21\end{array}$ & $\begin{array}{l}0.46 \\
0.63 \\
0.60 \\
0.47\end{array}$ & $\begin{array}{r}12.0 \\
10.3 \\
9.6 \\
8.5\end{array}$ & $\begin{array}{l}72 \\
70 \\
73 \\
72\end{array}$ & $\bar{z}$ & E & $\bar{z}$ & $\bar{z}$ \\
\hline $\begin{array}{l}A 61 \\
\text { a } \\
\text { b } \\
\text { c } \\
\text { d }\end{array}$ & $\begin{array}{l}1 \\
2 \\
1 \\
2 \\
1 \\
2 \\
1 \\
2\end{array}$ & $\begin{array}{l}1.73 \\
4.17 \\
1.16 \\
2.22 \\
1.62 \\
3.46 \\
2.33 \\
4.19\end{array}$ & $\begin{array}{l}1.52 \\
4.12 \\
1.04 \\
2.23 \\
1.67 \\
3.47 \\
2.29 \\
4.55\end{array}$ & $\begin{array}{l}0.50 \\
0.63 \\
0.38 \\
0.55 \\
0.23 \\
0.66 \\
0.70 \\
1.00\end{array}$ & $\begin{array}{r}4.5 \\
11.8 \\
4.3 \\
10.0 \\
6.7 \\
17.2 \\
8.0 \\
15.0\end{array}$ & $\begin{array}{l}83 \\
72 \\
77 \\
69 \\
72 \\
67 \\
71 \\
69\end{array}$ & $\begin{array}{l}3.28 \\
7.74 \\
2.39 \\
5.34 \\
4.92 \\
9.04 \\
5.17 \\
8.35\end{array}$ & $\begin{array}{l}23 \\
43 \\
16 \\
38 \\
25 \\
46 \\
38 \\
53\end{array}$ & $\begin{array}{l}1.1 \\
0.8 \\
2.8 \\
3.6 \\
2.8 \\
1.9 \\
3.7\end{array}$ & $\begin{array}{l}0.06 \\
0.10 \\
0.16 \\
0.13 \\
0.16 \\
0.24\end{array}$ \\
\hline $\begin{array}{l}A 63 \\
\text { a }\end{array}$ & $\begin{array}{l}1 \\
2 \\
3 \\
4 \\
1 \\
2 \\
3 \\
4 \\
1 \\
2 \\
1 \\
2 \\
3 \\
4\end{array}$ & $\begin{array}{l}1.12 \\
1.17 \\
1.14 \\
0.95 \\
1.11 \\
1.16 \\
1.02 \\
0.77 \\
1.80 \\
1.97 \\
0.91 \\
1.31 \\
1.06 \\
1.02\end{array}$ & $\begin{array}{l}1.64 \\
1.43 \\
1.29 \\
1.48 \\
2.23 \\
1.66 \\
1.20 \\
1.08 \\
2.68 \\
2.94 \\
1.54 \\
1.86 \\
1.59 \\
1.59\end{array}$ & $\begin{array}{l}0.16 \\
0.19 \\
0.21 \\
0.22 \\
0.31 \\
0.21 \\
0.24 \\
0.23 \\
0.38 \\
0.44 \\
0.19 \\
0.28 \\
0.23 \\
0.25\end{array}$ & $\begin{array}{l}5.2 \\
5.0 \\
5.0 \\
5.0 \\
7.2 \\
5.4 \\
5.8 \\
5.2 \\
6.3 \\
7.2 \\
6.1 \\
5.9 \\
6.1 \\
5.1\end{array}$ & $\begin{array}{l}68 \\
68 \\
69 \\
72 \\
68 \\
68 \\
68 \\
66 \\
70 \\
79 \\
62 \\
63 \\
69 \\
72\end{array}$ & $\begin{array}{l}3.90 \\
4.98 \\
4.75 \\
4.64 \\
5.12 \\
5.06 \\
4.49 \\
4.28 \\
5.75 \\
5.70 \\
4.84 \\
5.18 \\
4.31 \\
4.51\end{array}$ & $\begin{array}{l}44 \\
56 \\
72 \\
70 \\
45 \\
55 \\
69 \\
57 \\
43 \\
49 \\
41 \\
55 \\
44 \\
36\end{array}$ & $\begin{array}{l}4.1 \\
7.4 \\
5.7 \\
6.0 \\
6.4 \\
5.8 \\
4.4 \\
4.6 \\
8.6 \\
6.6 \\
5.0 \\
6.8 \\
5.5 \\
6.3\end{array}$ & $\begin{array}{l}0.13 \\
0.12 \\
0.15 \\
0.16 \\
0.15 \\
0.11 \\
0.13 \\
0.11 \\
0.19 \\
0.14 \\
0.15 \\
0.17 \\
0.16 \\
0.15\end{array}$ \\
\hline
\end{tabular}

* Specific activity is expressed as $\mu \mathrm{mol}$ substrate hydrolysed per mg protein per hour.

+ Specific activity is expressed as nmol substrate hydrolysed per mg protein per hour.

fibroblast-like cells derived from amniotic fluid has shown both similarities and specific differences between their respective enzyme contents (Gerbie et al, 1972; Kaback and Leonard, 1972). Such a division into two cell types would appear to be an over-simplification, since many more types may be present in amniotic fluid cell cultures (Uhlendorf, 1970). Furthermore, skin fibroblast cultures which are normally composed of a single cell type, show wide variation in enzymic activity (Milunsky et al, 1972). Quintuplet cultures derived from a single skin biopsy and treated identically were found to vary nearly 10 -fold with respect to the activities of several lysosomal hydrolases. We carried out a similar study to determine the variation in enzymic activity of cultures derived from a single specimen of amniotic fluid. In three separate experiments in which cultures were initiated in quadruplicate from a single fluid and treated identically, there was an approximate 2-fold variation in enzymic activity between the cultures (Table II). Cells obtained from the fluid of each amniotic sac of a twin pregnancy were also cultured. The cultures showed markedly different growth characteristics, one being composed mainly of fast-growing fibroblast-type cells and the other slow-growing epithelioid cells. 
Variability of acid hydrolase activities in cultured skin fibroblasts and amniotic fluid cells 227
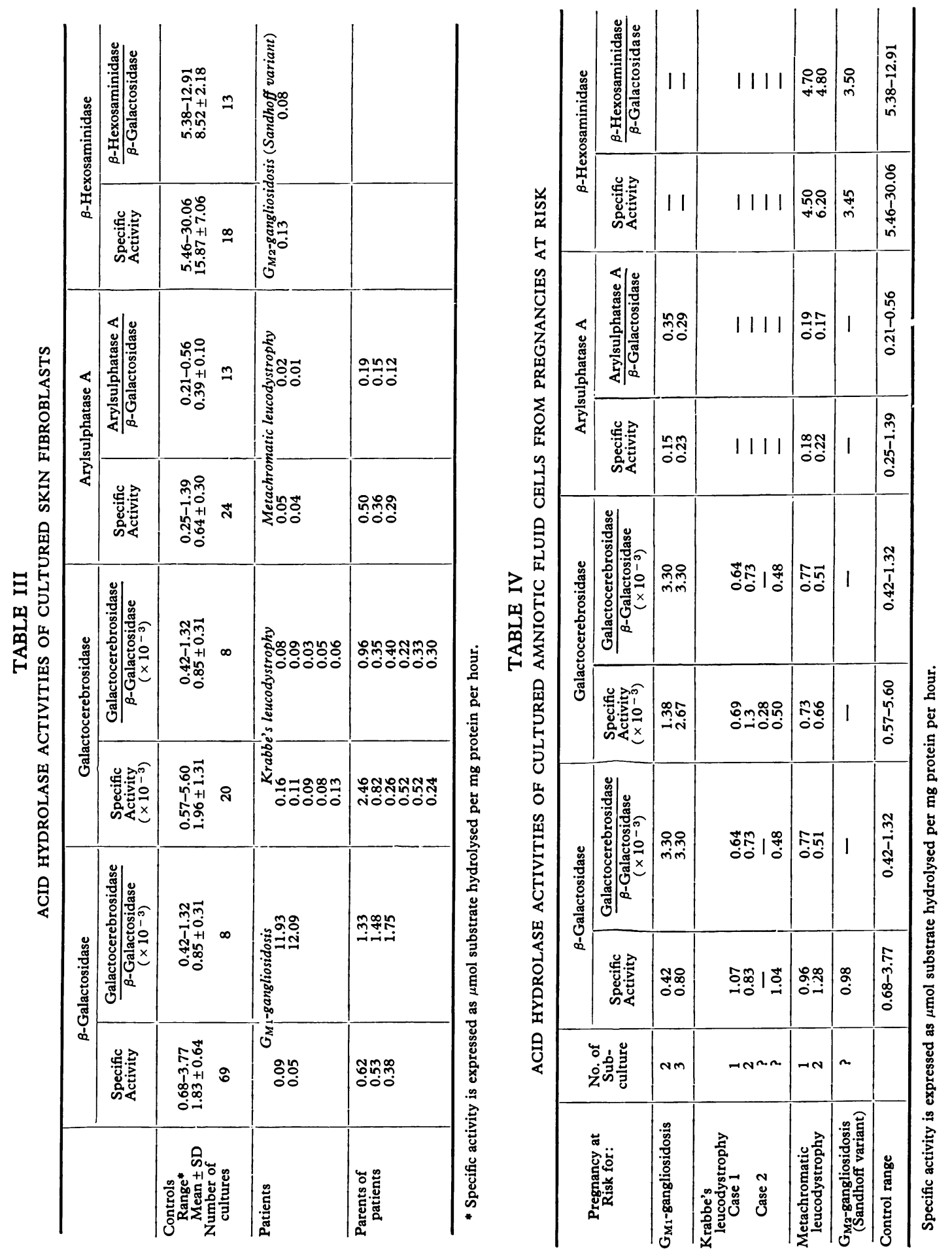

$\varliminf_{\mathbb{1}}^{\complement}$

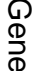

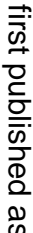

$\overrightarrow{0}$

$\dot{\vec{\omega}}$

䨔

$\vec{N}$

i

N

옥

$\overrightarrow{0}$

임

콩

융 जै

을일

음

옥

吾

כ)

훙

웅

웅

을.

సั

N

O

잉

$\stackrel{\mathbb{D}}{+}$

뭉

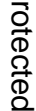


Enzymic activities of the cells harvested after two subcultures also showed marked differences, the slow-growing cells having approximately twice the activity of the fast-growing cells.

All the above findings confirm that current techniques and knowledge of cell culture do not permit strict control over the developmental patterns of lysosomal enzymes in cultured cells. Nevertheless, results showed that while the activities of individual enzymes varied widely between cultures, the degree of variation of activity for a given culture was similar for all enzymes assayed. Therefore, it appeared that a clearer differentiation of a relative deficiency in the activity of a particular enzyme might best be obtained by expressing that activity as a ratio to that of another enzyme. Experiments in which similarly cultured skin fibroblasts derived from control subjects, patients affected with a variety of lysosomal storage disorders and parents of these patients were compared, showed that wide ranges of activity were again found for control cultures, although the variability was less than that found for amniotic cell cultures. When these results were expressed as activity ratios the variability was considerably reduced (Table III). In all cases, activity ratios were useful in distinguishing homozygous, heterozygous and control cultures, and were particularly helpful in differentiating heterozygotes for metachromatic leucodystrophy. The only discrepancy was a result obtained for the father of a patient with Krabbe's leucodystrophy. The galactocerebrosidase activity of his skin fibroblasts consistently fell within the normal range whether related to protein or to $\beta$-galactosidase (or other enzyme). Normal values for galactocerebrosidase activity had previously been found for leucocytes prepared from several specimens of the father's blood. Blood group matching confirmed parenthood.

Present experience suggests that the use of activity ratios rather than specific activities will be particularly helpful in the evaluation of enzyme levels in amniotic fluid cells. As found for skin fibroblasts, the wide ranges of specific activity of individual enzymes of control cultures were narrowed considerably when expressed in ratio to the activity of $\beta$-galactosidase. The clearer differentiation obtained has been of practical use in prenatal diagnosis.

Pregnancies at risk for either metachromatic leucodystrophy, Krabbe's leucodystrophy, $\mathrm{G}_{\mathrm{M1}}$ gangliosidosis, or $\mathrm{G}_{\mathrm{M2}}$-gangliosidosis (Sandhoff variant) were monitored by enzymic analysis of cultured amniotic fluid cells. The fetuses at risk for metachromatic leucodystrophy or Sandhoff disease were considered normal; in the case of $\mathrm{G}_{\mathrm{M1}}$ gangliosidosis the fetus was predicted to be a hetero- zygote. All the diagnoses were confirmed at birth by enzymic analysis of leucocytes prepared from cord blood. Both fetuses tested for Krabbe's leucodystrophy were considered normal; this was confirmed at birth in one case, the other is proceeding to term. Activity ratios were particularly useful in one prenatal test for Krabbe's leucodystrophy in which a very low specific activity but normal activity ratio were found. Results of these tests are summarized in Table IV. Enzymic activity ratios have been used with advantage in postnatal diagnosis (den Tandt and Schaberg, 1973; Hall and Neufeld, 1973), but their use in the prenatal detection of lysosomal storage disorders has not been reported previously.

The importance of control work by a laboratory intending to offer a service in screening pregnancies at risk for metabolic disorders cannot be overstated. The ability to diagnose the diseased condition in leucocytes or cultured skin fibroblasts is not sufficient since in the majority of prenatal diagnoses there is a need for absolute differentiation between homozygous and heterozygous levels of enzymic activity. There must be no possibility that an exceptionally low heterozygous level of activity is interpreted as indicating an affected fetus. Similarly, a high residual activity in affected cells must not be interpreted as a low heterozygous level. Since the enzyme level of cultured cells is affected by many variables, it is essential that a laboratory attempting prenatal diagnoses should conduct an exhaustive investigation into the enzymology of amniotic fluid cells cultured according to a strictly controlled practice. The enzymic activities of cultured amniotic fluid cells determined by different workers cannot be directly compared, nor can results obtained for other cell types be applied to the evaluation of activities of cultured amniotic fluid cells (Brock, 1973). It has been shown that the enzymic activities of amniotic fluid cell cultures may vary greatly between subcultures. Therefore, when monitoring a pregnancy at risk, the enzyme assay should be carried out on at least two different subcultures. A control culture of amniotic fluid cells should also be processed using identical culture conditions. Uncultured cells from control amniotic fluids can be stored in liquid nitrogen and removed for culture when required, thus easing the problem of the availability of control cultures (Niermeijer et al, 1973).

We thank the Camilla Samuel Fund and the Joint Research Board of the Hospital for Sick Children Great Ormond Street and the Institute of Child Health for generous financial support. 


\section{REFERENCES}

Beutler, E., Kuhl, W., Trinidad, F., Teplitz, R., and Nadler, H. (1971). $\beta$-Glucosidase activity in fibroblasts from homozygotes and heterozygotes for Gaucher's disease. American fournal of Human Genetics, 23, 62-66.

Bowen, D. M. and Radin, N. S. (1969). Cerebroside galactosidase: a method for determination and a comparison with other lysosomal enzymes in developing rat brain. Fournal of Neurochemistry, 16, 501-511.

Brett, E. M., Ellis, R. B., Haas, L., Ikonne, J. U., Lake, B. D.,

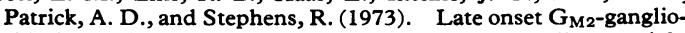
sidosis. Clinical, pathological and biochemical studies on eight patients. Archives of Disease in Childhood, 48, 775-785.

Brock, D. J. H. (1973). Biochemical studies on amniotic fluid cells. In Antenatal Diagnosis of Genetic Disease, ed. by A. E. H. Emery, pp. 82-112. Churchill Livingstone, London.

Butterworth, J., Sutherland, G. R., Broadhead, D. M., and Bain, A. D. (1973). Lysosomal enzyme levels in human amniotic fluid cells in tissue culture. I. $\alpha$-Glucosidase and $\beta$-glucosidase. Life Sciences, 13, 713-722.

Cristofalo, V. J., Parris, N., and Kritchevsky, D. (1967). Enzyme activity during the growth and ageing of human cells in vitro. Fournal of Cellular Physiology, 69, 263-272.

Ellis, R. B., Ikonne, J. U., Patrick, A. D., Stephens, R., and Willcox P. (1973). Prenatal diagnosis of Tay-Sachs disease. Lancet, 2 , 1144-1145.

Gerbie, A. B., Melancon, S. B., Ryan, C., and Nadler, H. L. (1972)。 Cultivated epithelial-like cells and fibroblasts from amniotic fluid: their relationship to enzymatic and cytologic analysis. American fournal of Obstetrics and Gynecology, 114, 314-320.

Hall, C. W. and Neufeld, E. F. (1973). $\alpha$-L-iduronidase activity in cultured skin fibroblasts and amniotic fluid cells. Archives of Biochemistry and Biophysics, 158, 817-821.

Holliday, R. (1972). Ageing of human fibroblasts in culture: Studies on enzymes and mutation. Humangenetik, 16, 83-86.

Hors-Cayla, M. C., Maroteaux, P. and de Grouchy, J. (1968). Fibroblasts en culture au cours de mucopolysaccharidoses: Influence du sérum sur la métachromasie. Annales de Génétique, 11, 265-266.

Kaback, M. M. and Howell, R. R. (1970). Infantile metachromatic leucodystrophy: Heterozygote detection in skin fibroblasts and possible applications to intrauterine diagnosis. New England Fournal of Medicine, 282, 1336-1340.

Kaback, M. M. and Leonard, C. O. (1972). Morphulogical and enzymological considerations in antenatal diagnosis. In Antenatal Diagnosis, ed. by A. Dorfman, pp. 81-94. University of Chicago Press, Chicago and London.
Kittlick, P. D., Neuport, G , and Lümkemann, U. (1973). Effect of different sera on mucopolysaccharide synthesis in fibroblast cultures. Experimentelle Pathologie, 8, 194-204.

Leroy, J. G., Dumon, J., and Radermecker, J. (1970). Deficiency of arylsulphatase $A$ in leucocytes and skin fibroblasts in juvenile metachromatic leucodystrophy. Nature, 226, 553-554.

Lowry, O. H., Rosenbrough, N. J., Farr, A. L., and Randall, R. J. (1951). Protein measurement with the Folin phenol reagent. fournal of Biological Chemistry, 193, 265-275.

Milunsky, A., Spielvogel, C., and Kanfer, J. N. (1972). Lysosomal enzyme variations in cultured normal skin fibroblasts. Life Sciences, 11, 1101-1107.

Niermeijer, M. F., Halley, D., Sachs, E., Tichelaar-Klepper, C., and Garver, K. L. (1973). Transport and storage of amniotic fluid samples for prenatal diagnosis of metabolic diseases. Humangenetik, 20, 175-178.

Okada, S., Veath, M. L., Leroy, J., and O'Brien, J. S. (1971). Ganglioside $\mathrm{GM}_{2}$ storage diseases: Hexosaminidase deficiencies in cultured fibroblasts. American Fournal of Human Genetics, 23, 55-61.

Pan, Y.-L. and Krooth, R. S. (1968). The influence of progressive growth on the specific catalase activity of human diploid cell strains. Fournal of Cellular Physiology, 71, 151-160.

Radin, N. S. and Arora, R. C. (1971). A simplified assay method for galactosyl ceramide $\beta$-galactosidase. Fournal of Lipid Research, 12, 256-257.

Russell, J. D. (1969). Variation in UDPGlu: $\alpha-D-G a l-1-P$ uridyl transferase activity during growth of cultured fibroblasts. In Galactosemia, ed. by D.Y.-Y. Hsia, pp. 204-212. Thomas, Springfield, Illinois.

Ryan, C. A., Lee, S. Y., and Nadler, H. L. (1972). Effect of culture conditions on enzyme activities in cultivated human fibroblasts. Experimental Cell Research, 71, 388-392.

Tandt, W. R. den and Schaberg, A. (1973). Mucopolysaccharide storage diseases and lysosomal hydrolases in cultured fibroblasts. Pathologia Europaea, 8, 3-12.

Uhlendorf, B. W. (1970). Use of amniotic fluid and reliability of diagnostic procedures. In Early Diagnosis of Human Genetic Defects, ed. by M. Harris, pp. 149-168. Government Printing Office, Washington.

Young, E. P., Ellis, R. B., and Patrick, A. D. (1972). Leukocyte $\beta$-galactosidase activity in $\mathrm{GM}_{1}$-gangliosidosis. Pediatrics, 50, 502-503.

Young, E. P. and Patrick, A. D. (1970). Deficiency of acid esterase activity in Wolman's disease. Archives of Disease in Childhood 45, $664-668$.

The result for the second pre-natal test for Krabbe's leucodystrophy has now been confirmed at birth.

Additional tests have included two for Krabbe's leucodystrophy (predicted normal; one confirmed at birth, the other is proceeding to term) and one for metachromatic leucodystrophy (predicted normal and confirmed at birth). 